\title{
Experimental Study of the Effect of Cooling Lubricating Fluids on Penetration Rate in a Hard and Soft Rock Drilling Process
}

Rudarsko-geološko-naftni zbornik

(The Mining-Geology-Petroleum Engineering Bulletin) UDC: 622.2

DOI: $10.17794 / \operatorname{rgn} .2021 .5 .8$

Original scientific paper

\author{
Shahrokh Khosravimanesh'; Masoud Cheraghi Seifabad²; Reza Mikaeil3; Raheb Bagherpour ${ }^{4}$ \\ ${ }^{1}$ Department of Mining Engineering, Isfahan University of Technology (IUT), Isfahan, Iran, P.O.Box: 84156-83111 \\ ${ }^{2}$ Department of Mining Engineering, Isfahan University of Technology (IUT), Isfahan, Iran, P.O.Box: 84156-83111 \\ ${ }^{3}$ Department of Mining and Engineering, Faculty of Environment, Urmia University of Technology, Urmia, Iran \\ ${ }^{4}$ Department of Mining Engineering, Isfahan University of Technology (IUT), Isfahan, Iran, P.O.Box: 84156-83111
}

\begin{abstract}
ROP (rate of penetration) can be improved through the proper use of cooling lubricating fluids during drilling. ROP is a key indicator of drilling performance and the ability to predict this rate can be very useful for mining projects. ROP prediction can also be used to estimate the total cost of a drilling operation. ROP depends on a variety of parameters, which, when available, can be used to estimate ROP. To reach a better understanding of the parameters affecting ROP and how it can be optimized, in this study, the results of 492 laboratory drilling tests were analyzed by linear and nonlinear multivariate regression in SPSS to build a number of models for ROP prediction. These tests were conducted on seven soft and hard rock samples while using six fluids as the cooling lubricating agent. The tests were performed with a laboratoryscale drilling rig on cubic specimens at several different rotation speeds and thrust forces. The results showed that drilling achieved a significantly higher ROP in the presence of a cooling lubricating agent. After reviewing the results, several models that were able to produce ROP predictions with the lowest average estimation error were chosen as suitable choices for predicting ROP in the presence of cooling lubricating fluids. The results of the statistical tests of these models showed with over 90\% confidence that they can produce highly accurate ROP estimates based on the mechanical properties of the rock, the physical characteristics of the cooling lubricating fluid, and the operating parameters of the drilling rig.
\end{abstract}

\section{Keywords:}

drilling; rate of penetration; cooling lubricating fluid; multivariate statistical analysis; SPSS

\section{Introduction}

Drilling is one of the most important operations of the mining industry, frequently performed in all stages of exploration and extraction (Bhatnagar and Khandelwal, 2012). Drilling operations play a major role in the cost efficiency and general performance of many mining and oil industry projects (Moraveji and Naderi, 2016). Given the high cost of drilling operations and machinery, it is crucial to optimize these operations; an effort that will require proper knowledge of all the parameters involved in the drilling process. Proper knowledge of the drilling environment and characteristics of the drilled rock will also be very helpful in choosing the right type of drilling system, estimating the production capacity, and predicting the drilling rate (Hoseinie et al., 2008). With an accurate estimate of the rate of penetration (ROP), one can also predict the total cost of drilling. Such predictions can also be utilized to determine the most suitable type of drilling rig for certain conditions

Corresponding author: Reza Mikaeil

Reza.mikaeil@gmail.com
(Kahraman 1999). ROP generally depends on the drilling rig specifications and geological conditions and properties of the drilled rock (Yagiz and Karahan, 2015). While geological conditions and rock properties are uncontrollable parameters of drilling, drilling rig parameters, including the size and type of drill bit, thrust force, drill rotation speed, and type and flow rate of drilling fluid are generally controllable (Cheniany et al., 2012). Many studies have investigated the relationship between drilling rig parameters and ROP in a variety of rocks (Miller and Ball, 1990; Miller and Ball, 1991; Rao, 1993). In projects that involve diamond drilling, it is possible to improve ROP, drill bit lifetime and wear rate, energy consumption, and general cost-efficiency of the project by enhancing the drilling operation performance. This enhancement can be done through the proper use of cooling lubricating fluids during drilling (Zhao et al., 2011).

In the last 50 years, researchers have tried a variety of methods to improve the efficiency of drilling operations, one of which is to use chemical additives to enhance the surface properties of rocks (Hammond and Ravitz, 
1963; Selim et al., 1969; Tweeton, 1976; Mills and Westwood, 1978; Westwood et al., 1981; Pahlman, 1989). Adding these chemicals to the drilling fluid to affect the bit-rock interface tends to significantly increase the drilling rate, which results in increased ROP and reduced energy consumption (El-Shall et al., 2000). In a study by Clark (1987) on the factors affecting rock fractures, the results showed that the friction and thermal stresses at the bit-rock interface cannot be reduced more than a certain amount while using water as the drilling fluid, and it is possible to achieve a better drilling rate and energy consumption by using other fluids to provide better cooling and lubricating conditions and ensure the better removal of cuttings from the drilling environment (Clark, 1987). A study by Tuzinski et al. (1989) on the effect of using chemical additives in drilling fluid on drilling performance reported that adding ionic and nonionic polymers to water significantly increases ROP and the bit lifespan (Tuzinski et al., 1989). Loui and Rao (1997) investigated the effect of cooling fluid and rig operating parameters on the drilling and cutting performance of diamond drilling tools. These researchers reported that in dry drilling, especially in hard rocks, thermal stresses due to friction at the bit-rock interface have a major impact on the bit wear rate. They added that tungsten carbide bits exhibit sharply reduced hardness at $500^{\circ} \mathrm{C}$ and above, but the use of a cooling fluid can significantly reduce the bit wear rate and increase the drilling performance (Loui and Rao, 1997). Staroselsky and Kim (1997) analyzed the effect of using mixtures of surfactant additives and water as a drilling fluid on the drilling rate. This study showed that the good drilling performance in the presence of surfactant-containing fluid is due to not only the chemical effects of the surfactant, but also the combination of mechanical and chemical interactions. Using rock fracture mechanics and an analysis of the cuttings, they showed that the cracks created in the rock and the cuttings produced during drilling with surfactant-containing water were two times larger than those in drilling with plain water (Staroselsky and Kim, 1997). Altindag (2004) studied the relationship between roughness and average size of drill cuttings and ROP in percussive drilling operations. The results of the regression analysis of this study showed that there are consistent relationships between ROP and roughness index and average particle size, which means they can be used to predict ROP (Altindag, 2004). In a series of studies by Bhatnagar et al. $(2010,2011)$ on whether the performance of diamond drilling operations can be improved by using mixtures of non-ionic polymers and water as the cooling lubricating fluid, the results showed that using this mixture instead of plain water increased ROP at all drill rotation speeds and thrust forces (Bhatnagar et al., 2010; Bhatnagar et al., 2011). In a study by Zhao et al. (2011), where they investigated the effect of using mineral additives, such as calcium chloride $\left(\mathrm{CaCl}_{2}\right)$, aluminum chloride $\left(\mathrm{AlCl}_{3}\right)$, aluminum sulfate $\mathrm{Al}_{2}\left(\mathrm{So}_{4}\right)_{3}$, and ZJBS surfactant (anionic surfactant and it releases surface-active ion with negative charges in the solution) on ROP in sandstone, the results showed that using these additives increased ROP (Zhao et al., 2011). In a study by Bhatnagar and Khandelwal (2012) on the impact of rig operating parameters on ROP, the artificial neural network method was used to build a model for predicting ROP (Bhatnagar and Khandelwal, 2012). Aalizad and Rashidinejad (2012) also used the artificial neural network method to build a model for predicting ROP in rotary-percussive drilling operations. The results of this study showed a high correlation between ROP and rock properties and rig operating parameters (Aalizad and Rashidinejad, 2012). In a study by Gupta et al. (2013) on the effect of the bit wear rate on drilling performance, the results showed that bit wear rate primarily depends on the hardness and abrasivity of the rock and its quartz content, and the thermal stresses caused by excessive heat increase the wear rate. It was also stated that to optimize the drilling operation, it is necessary to strike a balance between wear rate and ROP. These researchers also stated that the presence of a cooling fluid can reduce the wear rate and increase drilling performance by cooling the bit and removing cuttings from the drill hole (Gupta et al., 2013). Basarir et al. (2014) investigated whether it is possible to predict ROP in diamond drilling based on rock properties and rig operating parameters. The results of multivariate regression models of this study showed that rock properties and rig operating parameters can be used to predict ROP with an acceptable correlation coefficient (Basarir et al., 2014).

The results of a series of laboratory experiments conducted by Kivade et al. (2015) on the effect of rock mechanical properties and rig parameters on ROP showed that ROP is positively correlated with thrust force and inversely correlated with rock strength and abrasivity. Using multivariate regression analysis, this researcher also constructed a model for the relationship between ROP and rock properties and rig operating parameters (Kivade et al., 2015a). Kivade et al. (2015) used the artificial neural network method to build models for predicting ROP and rock properties based on drilling noise. The results of this study showed that the models developed for predicting rock properties were of higher quality (Kivade et al., 2015b). In a study by Rawal et al. (2016) on the effect of using mixtures of three polymeric additives and water as a drilling fluid on ROP in sandstone, the results showed that using certain concentrations of these additives improves ROP and the friction at the bit-rock interface (Rawal et al., 2016). In an article by Taheri et al. (2016), these researchers provided an index for predicting ROP. One of the main parameters of this index is the uniaxial compressive strength of the rock (Taheri et al., 2016). The numerical models developed by Van Hung et al. (2016) for the prediction of ROP in hard rock drilling showed that there is a significant relationship with a high correlation coefficient be- 


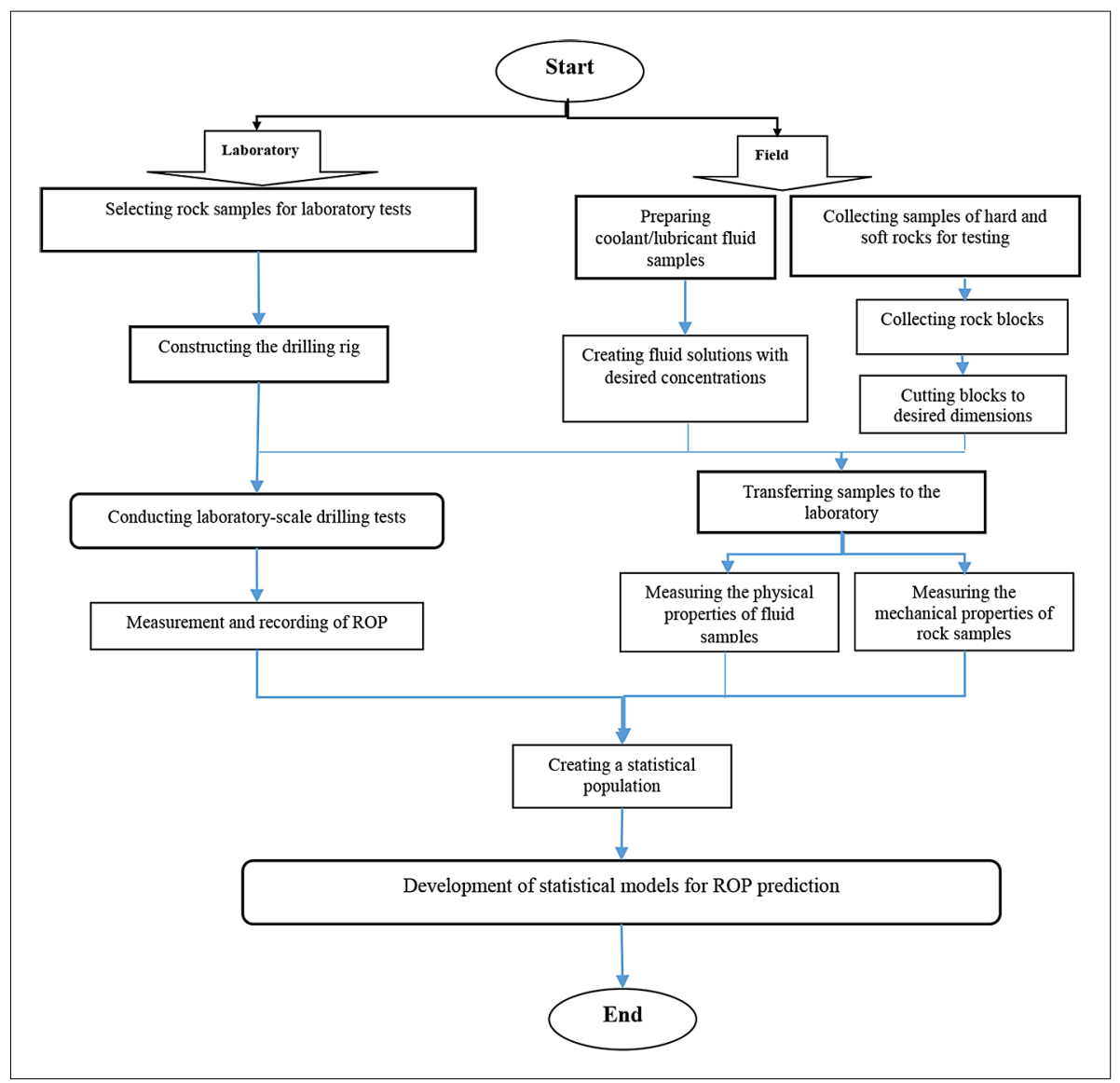

Figure 1: Flowchart of the research process

tween ROP and the properties of these rocks (Van Hung et al., 2016). Azar et al. (2017) used the artificial neural network method and linear multivariate analysis to build models for predicting ROP. The results of these researchers showed that neural networks and regression models can offer accurate estimates of ROP and are useful tools for cost and time saving in drilling operations (Azar et al., 2017). In a study by Shad et al. (2018) on the prediction of ROP in rotary drilling in iron ore, the results showed that the rock properties and iron oxide content, and rig operating parameters have a great impact on ROP estimates (Shad et al., 2018). Yari and Bagherpour (2018) developed a new model for describing the physical properties of sedimentary rocks using dominant acoustic frequencies generated during drilling. They concluded that there are significant mathematical relationships between the properties of sedimentary rocks and the dominant acoustic frequencies (Yari and Bagherpour, 2018a). Using Fourier Transform, Yari and Bagherpour (2018) presented mathematical relationships between rock mass classification and the dominant acoustic frequencies generated during drilling process (Yari and Bagherpour, 2018b). Yari et al (2019) developed a new model for predicting the geomechanical characteristics of carbonate rocks by processing the acoustic frequencies generated during drilling (Yari et al., 2019). Khoshouei et al (2020) studied the acoustic signs of different types of rock based on the value of the acoustic signal RMS. They showed that using the RMS values obtained from the acoustic signals, rock class and rock strength characteristics can be estimated (Khoshouei et al., 2020). Zhao et al. (2020) developed a new method for predicting and optimizing ROP with artificial neural network algorithms. The results of this study showed that the developed model is accurate enough for ROP prediction and optimization (Zhao et al., 2020). Elkatatny et al. (2020) also used artificial neural networks to develop a new model for ROP prediction, ultimately showing that the proposed model can predict ROP with a high correlation coefficient (Elkatatny et al., 2020). In a study by Liao et al. (2020) on ROP prediction and optimization with intelligent neural networks, the results showed that intelligent systems can provide excellent models for predicting ROP and optimizing drilling conditions (Liao et al., 2020). Yassien et al. (2020) conducted some experiments on the influence of some operational parameters and rock characteristics on the penetration rate. The results showed that penetration rate is inversely correlated with compressive and tensile strength as well as the density of rock, while it has a direct relation with porosity. Moreover, in low and high rotation speeds, the penetration rate increases with an increase in thrust (Yassien et al., 2020). Lawal et al (2021) used a combination of statistical models and arti- 


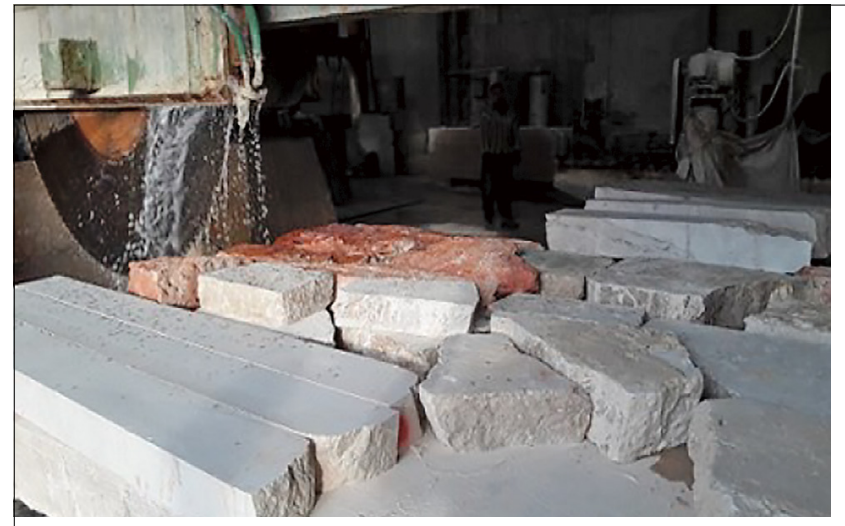

a)

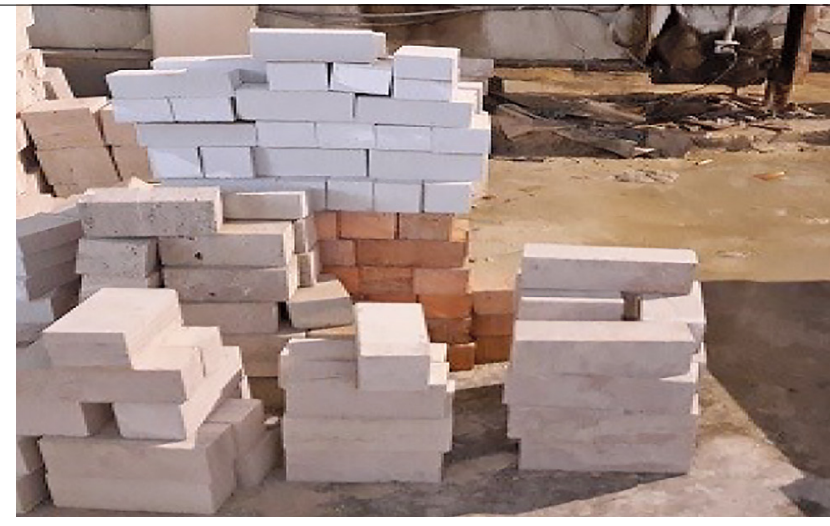

b)

Figure 2: Rock sampling procedure: a) cutting of rock samples; b) preparation of samples for transferring to laboratory

Table 1: Name and type of the collected rock samples

\begin{tabular}{|l|l|l|l|}
\hline Type of rock & Name of quarry & $\begin{array}{l}\text { Commercial } \\
\text { name }\end{array}$ & $\begin{array}{l}\text { Rock } \\
\text { sample }\end{array}$ \\
\hline Hard & Sefid Natanz & Granite & A1 \\
\hline Hard & Khoramdare & Granite & A2 \\
\hline Hard & Khoshtinat & Granite & A3 \\
\hline Soft & Salsali & Marble & A4 \\
\hline Soft & Harsin & Marble & A5 \\
\hline Soft & Hajiabad & Travertine & A6 \\
\hline Soft & Azarshahr & Travertine & A7 \\
\hline
\end{tabular}

Table 2: Brand, concentration, and abbreviation of the chosen fluids

\begin{tabular}{|l|l|l|}
\hline Abbreviation & Name/Brand & $\begin{array}{l}\text { Fluid } \\
\text { sample }\end{array}$ \\
\hline FW & Water & $\mathrm{B}_{1}$ \\
\hline FSW $_{1}$ & $\begin{array}{l}\text { Soap water with a concentration } \\
\text { of } 1 / 66 \%\end{array}$ & $\mathrm{~B}_{2}$ \\
\hline $\mathrm{FSW}_{2}$ & $\begin{array}{l}\text { Soap water with a concentration } \\
\text { of } 0.83 \%\end{array}$ & $\mathrm{~B}_{3}$ \\
\hline $\mathrm{FS}_{1}$ & $\begin{array}{l}\text { Syncool with a concentration } \\
\text { of } 1 \%\end{array}$ & $\mathrm{~B}_{4}$ \\
\hline $\mathrm{FS}_{2}$ & $\begin{array}{l}\text { Syncool with a concentration } \\
\text { of } 0.66 \%\end{array}$ & $\mathrm{~B}_{5}$ \\
\hline $\mathrm{FBN}$ & $\begin{array}{l}\text { Boron Nitride Powder } \\
\text { with a concentration of } 25 \%\end{array}$ & $\mathrm{~B}_{6}$ \\
\hline
\end{tabular}

All concentrations are in the litres of additive solved in the specified litres of water

ficial neural networks to predict ROP in drilling operations (Lawal et al., 2021). A study by Bilim and Karakaya (2021) provided several models for predicting ROP in exploratory borehole drilling operations. The results of this study showed that the developed models can accurately predict ROP based on the physical and mechanical properties of the rock (Bilim and Karakaya, 2021).

As the above review indicates, the majority of past studies on ROP prediction and the impact of a cooling lubricating fluid on drilling performance have been focused on the effect of drilling rig operating parameters and rock properties on ROP prediction. Thus, the literature can benefit from a comprehensive study of the effect of physical properties of cooling lubricating fluids, as well as the effect of physical-mechanical properties of the drilled rock and rig operating parameters in the presence of these fluids on ROP prediction. Given the importance of ROP prediction for improving drilling cost, rate, and efficiency, this study investigated the simultaneous effect of mechanical properties of the rock (uniaxial compressive strength, Young's modulus, Mohs hardness, and Schmiazek abrasivity factor), properties of the cooling lubricating fluid $(\mathrm{pH}$, viscosity, and conductivity) and operating parameters of the drilling rig (thrust force and drill rotation speed) on ROP prediction.

\section{Materials and Methods}

This study was conducted in two phases aimed at building a statistical population for statistical analysis with linear and nonlinear multivariate regression in SPSS. The first phase was field studies, which involved the conduction of some studies on dimension stones and cooling lubricating fluids in order to choose rock and cooling fluids samples. The second phase was laboratory studies, which involved running a series of tests to determine the physical properties of rock and fluid samples, building a laboratory-scale drilling rig, and finally conducting a series of drilling tests to gather data for ROP prediction. Figure 1 shows the flowchart of the research process.

\subsection{Field and laboratory studies}

After examining the literature on rock properties, it was decided to conduct the tests on seven rock samples collected from multiple Iranian quarries (see Figure 2), the list of which is given in Table $\mathbf{1}$.

Also, after examining the literature on cooling lubricating fluids, it was decided to run the tests with the flu- 
Table 3: Important mechanical properties of the studied rocks.

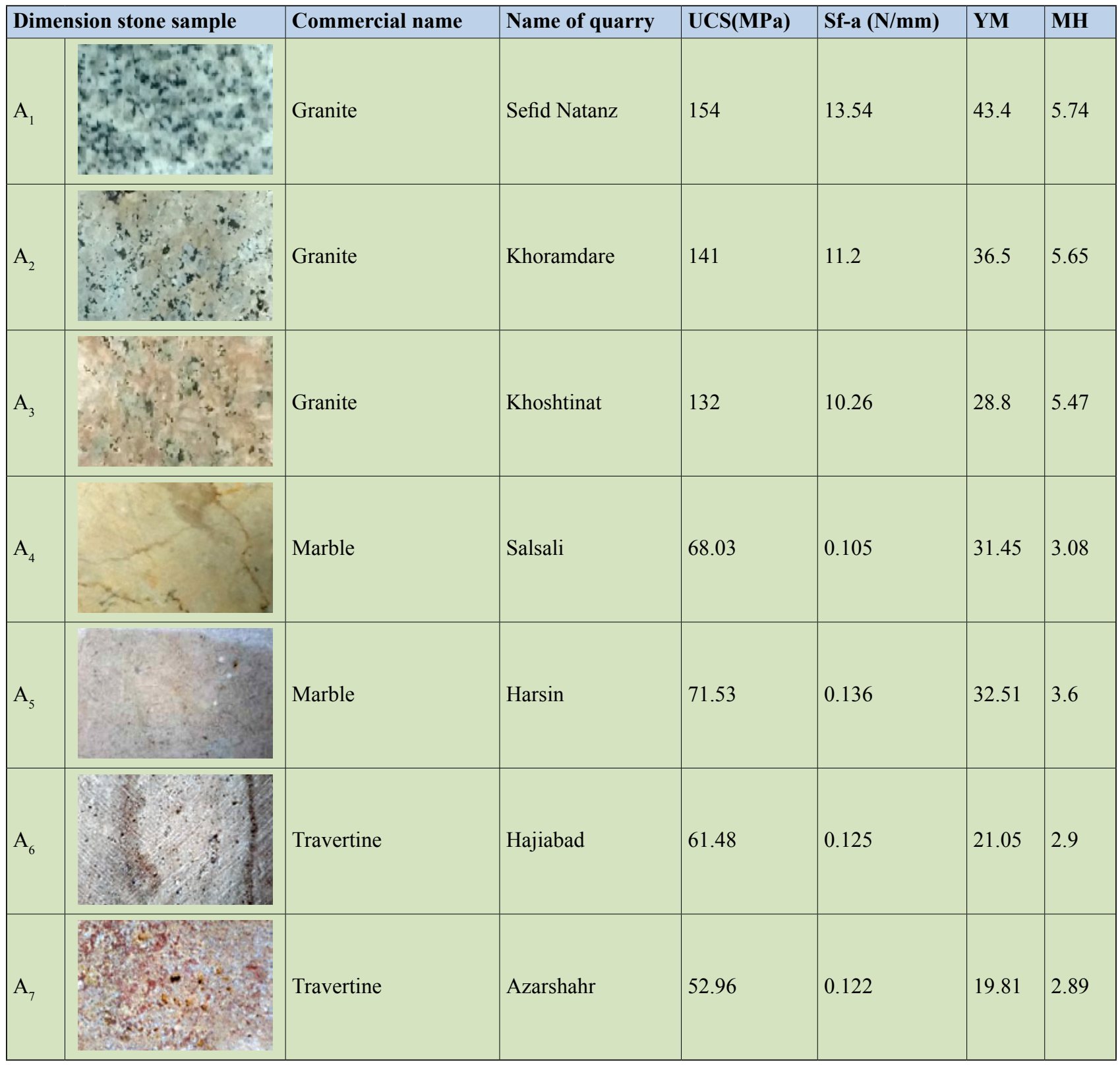

ids listed in Table 2, which were chosen for their cooling lubricating properties and specifications. Also provided in Table 2 are the concentrations chosen for these fluids and the codes used to refer to their specimens.

After collecting rock samples, which included three samples of hard rock and four samples of soft rock, they were transferred to the rock mechanics laboratory and cut to specific dimensions so that they can be subjected to tests of physical and mechanical properties as well as drilling tests.

The first series of tests conducted on the collected rock samples included standard tests for measuring the following four mechanical properties:

(a) Uniaxial Compressive Strength (UCS),

(b) Schmiazek abrasivity factor (SF-a), (c) Young's Modulus (YM),

(d) Mohs Hardness (MH).

The rock samples to be used in the tests were chosen based on the following criteria: being large enough so that all tests can be conducted on the same sample, select the samples of rocks with minimum fractures and altered areas to be almost close to an intact rock sample, and not showing macroscopic defects in the secondary examination. The tests of the above properties were conducted according to the ISRM standard (Brown 1981).

To measure the uniaxial compressive strength (UCS), which counts among the most important and most widely used rock properties, a diamond core drill was used to cut out five standard specimens with a length to diameter ratio of 2.5:1 from each block. After polishing, these 
Table 4: Physical properties of the studied fluids.

\begin{tabular}{|l|l|l|l|l|l|}
\hline $\begin{array}{l}\text { Fluid } \\
\text { sample }\end{array}$ & Commercial name & $\begin{array}{l}\text { Concentration of the } \\
\text { additive in the water }\end{array}$ & Vis(mPa.s) & pH value & EC( $\boldsymbol{\mu s} / \mathbf{c m})$ \\
\hline $\mathrm{B}_{1}$ & water & - & 1.012 & 7.65 & 386 \\
\hline $\mathrm{B}_{2}$ & Soap water & $1.66 \%$ & 1.312 & 9.25 & 147.3 \\
\hline $\mathrm{B}_{3}$ & Soap water & $0.83 \%$ & 1.295 & 9.81 & 102.5 \\
\hline $\mathrm{B}_{4}$ & Syncool & $1 \%$ & 1.381 & 9.39 & 166.4 \\
\hline $\mathrm{B}_{5}$ & Syncool & $0.66 \%$ & 1.196 & 8.86 & 152.8 \\
\hline $\mathrm{B}_{6}$ & Boron nitride powder & $25 \%$ & 8.17 & 8.17 & 238.9 \\
\hline
\end{tabular}

specimens were subjected to a load of 1-1.2MPa until fracture. The obtained measurements were then used to compute the mean UCS of each rock sample.

To quantify the abrasivity of rock samples, their Schmiazek abrasivity factor was obtained using Equation 1 (Ersoy and Waller 1995).

$$
S F-a=\frac{E Q C \times G s \times B T S}{100}
$$

Where:

SF-a - Schimazek's wear factor $(\mathrm{N} / \mathrm{mm})$,

$\mathrm{EQC}$ - equivalent quartz content percentage (\%),

Gs - median grain size $(\mathrm{mm})$,

BTS - indirect Brazilian tensile strength (MPa).
To determine the mean hardness of rock samples, the thin sections taken from these samples were examined to determine the relative amount of each of their constituting minerals, and then an estimate of mean hardness was obtained from Equation 2 (Ersoy and Waller 1995):

$$
\text { Mean Hardness }=\sum_{i=1}^{n} M_{i} \times H_{i}
$$

Where:

$\mathrm{M}_{\mathrm{i}}$ - mineral amount (\%),

$\mathrm{H}_{\mathrm{i}}$ - Mohs hardness,

$\mathrm{n}$ - total number of minerals in the dimension stone.

The elastic modulus used in this study was Young's tangent modulus, which can be obtained from the slope

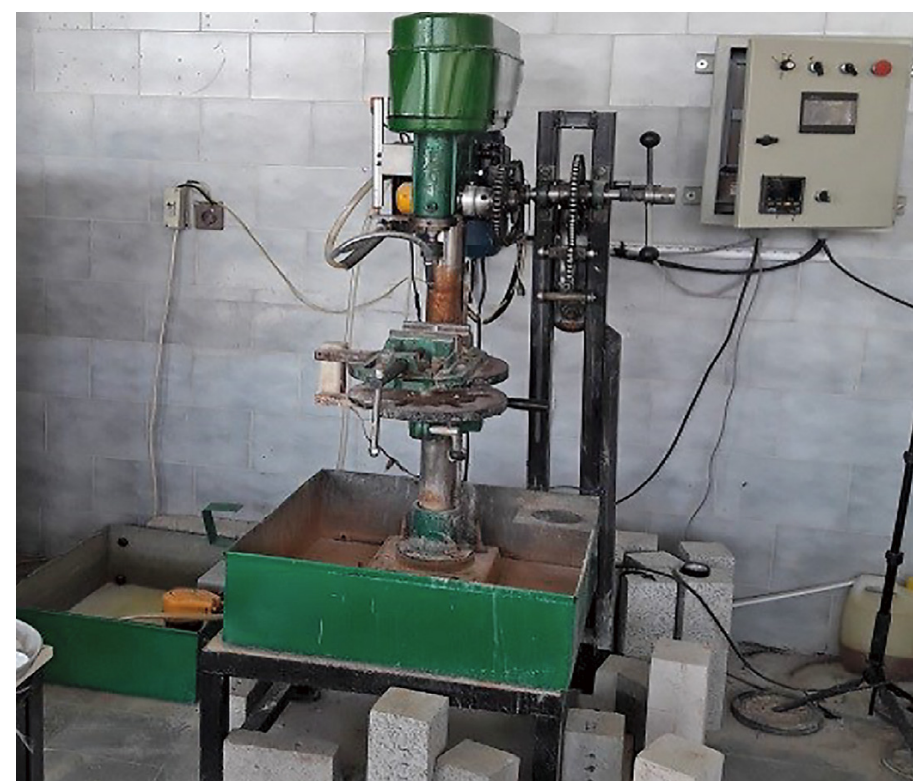

a)

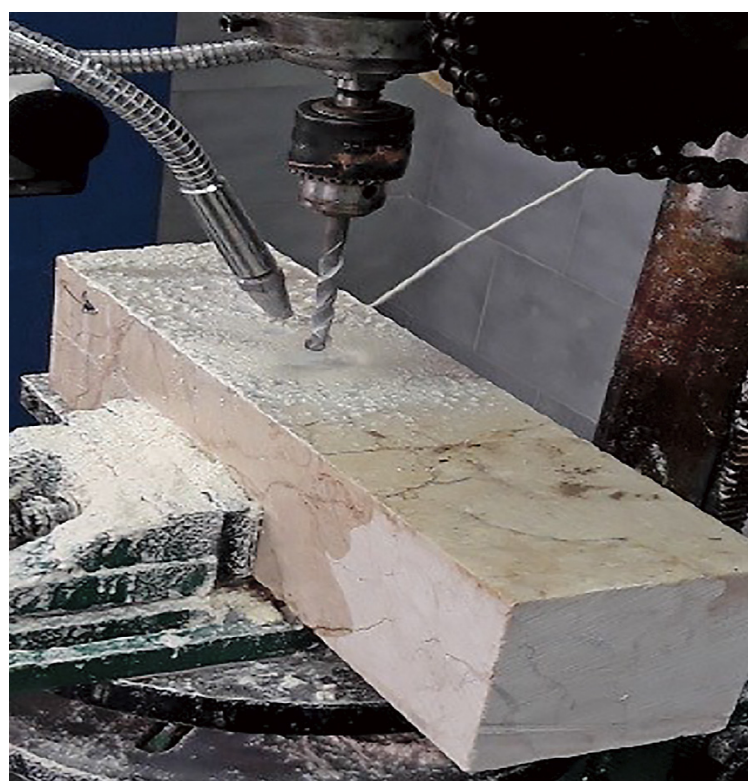

b)

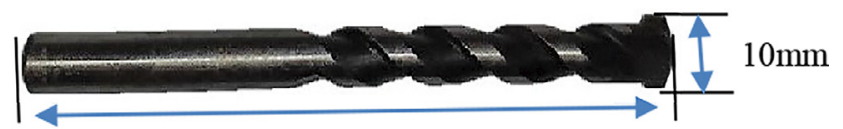

$120 \mathrm{~mm}$

c)

Figure 3: Drilling test tools: a) fabricated drilling rig; b) rock specimens prepared for the drilling test; c) drill bit used in the drilling test. 
of the line tangent to the axial stress-strain curve at a point with $50 \%$ of the ultimate strength. Table 3 shows the mechanical properties of the collected rock samples according to the above-described tests and measurements.

After determining the mechanical properties of rock samples, another series of laboratory tests were performed to determine the physical properties of the considered cooling lubricating fluids, including their $\mathrm{pH}$, viscosity (Vis), and conductivity (EC). Table 4 shows the $\mathrm{pH}$, viscosity, and conductivity of these fluids according to these tests.

All drilling tests of this study were performed with a laboratory-scale drilling rig designed and fabricated by the authors to make sure that the collected measurements are perfectly homogenous and reliable and avoid the data heterogeneity stemming from the use of different tools with different operating conditions in different mines.

This drilling rig consists of two main parts: a drill and a control panel. The control panel is equipped with a processor and a touch screen panel and is tasked with controlling and recording the drilling data. For each drilling test, the drill rotation speed and flushing condition must be specified through the control panel and the thrust force must be adjusted by changing the weights hanging beside the rig with a chain and gear system. After receiving the drilling instructions, the rig starts to drill the rock accordingly and measures ROP, torque, power consumption, and fluid flow rate at each instant of the drilling process. These data will be saved in a file, which can be extracted from the control panel. To prevent movement during drilling, the specimens must be firmly secured on a circular plate equipped with a clamp for this purpose. The cooling lubricating fluid must be poured into a tank placed at the bottom of the rig. During drilling, the fluid in this tank will be pumped out to a flushing system, which is placed next to the bit and can spray the fluid in any direction. The drilling tests of this study were performed with a $10 \mathrm{~mm}$ in diameter tungsten carbide bit with a diamond blade designed for drilling in hard rocks such as granite. The drill points were chosen so that they were at least $30 \mathrm{~mm}$ apart (more than twice the bit diameter) and at least $50 \mathrm{~cm}$ away from the block edge. An image of the drilling rig, the rock specimens prepared for the drilling test and the drill bit selected for the drilling tests is displayed in Figure 3.

The rock specimens needed for the tests were cut in $10 \times 10 \times 15 \mathrm{~cm}^{3}, 10 \times 10 \times 20 \mathrm{~cm}^{3}$, and $10 \times 10 \times 30 \mathrm{~cm}^{3}$ dimensions. Since the drilling tests could be performed with various different drill rotation speeds and thrust forces, we first conducted a number of tests with minimum and maximum rig power to determine the suitable rotation speed and thrust force for drilling in hard and soft specimens. After several trials and errors, we decided to use rotation speeds of 1190, 1057, and 933rpm and thrust forces of $1303,1137,931$, and $755 \mathrm{~N}$ for hard rock specimens and rotation speeds of $933,845,720$, and 610rpm and thrust forces of 1137, 931, 755 and $568 \mathrm{~N}$ for soft rock specimens. For soft rock specimens $\left(\mathrm{A}_{4}, \mathrm{~A}_{5}, \mathrm{~A}_{6}, \mathrm{~A}_{7}\right)$, drilling tests were performed with water and five other cooling lubricating fluids, namely $\mathrm{FS}_{1}$, $\mathrm{FS}_{2}, \mathrm{FSW}_{1}, \mathrm{FSW}_{2}$, and FBN. Considering the results of these tests, it was decided to drill the hard rocks with the fluids that gave the highest ROP in soft rocks, which were $\mathrm{FS}_{1}$ and $\mathrm{FSW}_{2}$. Overall, 384 tests on soft rocks (64 for each of the six fluids) and 108 tests on hard rocks (36 for each of the three fluids) were conducted. The results of these 492 tests were analyzed to determine the mutual impact of mechanical properties of rocks, physical properties of cooling lubricating fluids, and rig operating parameters on ROP prediction for three fluids for hard rock and six fluids for soft rock specimens.

\section{Result}

The relationship between ROP and the mechanical properties of rocks, physical properties of fluids, and rig operating parameters were investigated with linear and nonlinear multivariate regression.

The following statistical models show the relationship between ROP and rock properties, fluid properties, and rig operating parameters.

$$
\begin{gathered}
\mathrm{ROP}=0.026 \mathrm{Th}+0.002 \mathrm{SR}+ \\
+0.4958 \mathrm{PH}-0.009 \mathrm{UCS}+0.112 \mathrm{SF}-\mathrm{a}- \\
-0.108 \mathrm{YM}-0.510 \mathrm{MH}-0.648 \\
\mathrm{ROP}=0.026 \mathrm{Th}+0.002 \mathrm{SR}-0.004 \mathrm{EC}+ \\
+0.115 \mathrm{SF}-\mathrm{a}-0.109 \mathrm{YM}-0.008 \mathrm{UCS}- \\
-0.497 \mathrm{MH}+4.405 \\
\mathrm{ROP}=0.026 \mathrm{Th}+0.002 \mathrm{SR}+ \\
+2.716 \mathrm{Vis}-0.506 \mathrm{MH}+0.113 \mathrm{SF}-\mathrm{a}- \\
-0.009 \mathrm{UCS}-0.108 \mathrm{YM}+0.388
\end{gathered}
$$

$$
\mathrm{ROP}=0.026 \mathrm{Th}+0.002 \mathrm{SR}+
$$$$
+0.599 \mathrm{PH}+0.001 \mathrm{EC}-0.009 \mathrm{UCS}-0.107 \mathrm{YM}-
$$$$
-0.513 \mathrm{MH}+0.111 \mathrm{SF}-\mathrm{a}-1.732
$$

$$
\begin{gathered}
\mathrm{ROP}=0.026 \mathrm{Th}+0.002 \mathrm{SR}-0.090 \mathrm{Vis}+ \\
+0.508 \mathrm{PH}-0.009 \mathrm{UCS}+0.112 \mathrm{SF}-\mathrm{a}- \\
-0.108 \mathrm{YM}-0.510 \mathrm{MH}-0.657
\end{gathered}
$$

$$
\begin{gathered}
\mathrm{ROP}=0.027 \mathrm{Th}+0.003 \mathrm{RPM}- \\
-0.002 \mathrm{EC}+1.207 \mathrm{Vis}-0.109 \mathrm{YM}-0.008 \mathrm{UCS}+ \\
+0.114 \mathrm{SF}-\mathrm{a}-0.500 \mathrm{MH}+2.667 \\
\mathrm{ROP}=0.026 \mathrm{Th}+0.002 \mathrm{SR}- \\
-0.086 \mathrm{Vis}+0.612 \mathrm{PH}+0.001 \mathrm{EC}+0.111 \mathrm{SF}-\mathrm{a}- \\
-0.513 \mathrm{MH}-0.107 \mathrm{YM}-0.009 \mathrm{UCS}-1.740 \\
\mathrm{ROP}=\frac{\mathrm{Th}^{0.956} \times \mathrm{SR}^{0.749} \times \mathrm{PH}^{1.674} \times \mathrm{UCS}^{0.416}}{\mathrm{SF}-\mathrm{a}^{0.054} \times \mathrm{YM}^{1.443} \times \mathrm{MH}^{0.474} \times 10^{3.693}}
\end{gathered}
$$




$$
\begin{aligned}
& \mathrm{ROP}=\frac{\mathrm{Th}^{0.956} \times \mathrm{SR}^{0.749} \times \mathrm{UCS}^{0.417}}{\mathrm{EC}^{0.322} \times \mathrm{SF}-\mathrm{a}^{0.048} \times \mathrm{YM}^{1.442} \times \mathrm{MH}^{0.479} \times 10^{1.379}} \\
& \mathrm{ROP}=\frac{\mathrm{Th}^{0.956} \times \mathrm{SR}^{0.749} \times \mathrm{Vis}^{1.299} \times \mathrm{UCS}^{0.417}}{\mathrm{MH}^{0.477} \times \mathrm{SF}-\mathrm{a}^{0.051} \times \mathrm{YM}^{1.443} \times 10^{2.220}} \\
& \mathrm{ROP}=\frac{\mathrm{TH}^{0.955} \times \mathrm{SR}^{0.749} \times \mathrm{EC}^{0.052} \times \mathrm{PH}^{1.925} \times \mathrm{UCS}^{0.415}}{\mathrm{YM}^{1.443} \times \mathrm{MH}^{0.473} \times \mathrm{SF}-\mathrm{a}^{0.055} \times 10^{4.049}} \\
& \mathrm{ROP}=\frac{\mathrm{Th}^{0.956} \times \mathrm{SR}^{0.749} \times \mathrm{Vis}^{0.108} \times \mathrm{PH}^{1.553} \times \mathrm{UCS}^{0.416}}{\mathrm{SF}-\mathrm{a}^{0.054} \times \mathrm{YM}^{1.443} \times \mathrm{MH}^{0.474} \times 10^{3.588}} \\
& \mathrm{ROP}=\frac{T h^{0.956} \times S R^{0.749} \times V i s^{0.648} \times U C S^{0.417}}{E C^{0.191} \times Y M^{1.442} \times S F-a^{0.049} \times M H^{.0478} \times 10^{1.733}} \\
& \mathrm{ROP}=\frac{T h^{0.955} \times S R^{0.749} \times V i s^{0.024} \times P H^{1.874} \times E C^{0.047} \times U C S^{0.415}}{S F-a^{0.055} \times M H^{0.473} \times Y M^{1.443} \times 10^{3.992}}
\end{aligned}
$$

Where:

ROP - Rate of penetration in millimeter per second $(\mathrm{mm} / \mathrm{s})$,

UCS - uniaxial compressive strength in megapascal (MPa),

MY - elastic modulus (GPa),

SF-a - Schmiazek abrasivity factor $(\mathrm{N} / \mathrm{mm})$,

$\mathrm{MH}$ - Mohs hardness,

Vis - viscosity (mPa.s),

EC - conductivity ( $\mu \mathrm{s} / \mathrm{cm})$,

$\mathrm{PH}$ - acidity in terms of $\mathrm{pH}$,

Th - thrust force $(\mathrm{N})$,

SR - drill bit rotation speed (RPM).

In all the models, ROP was considered as a dependent variable and rock properties, fluid properties, and rig operating parameters were considered as independent variables. F and t-tests were used to analyze and control the obtained models. The process of model control and validation is shown in the flowchart of Figure 4.

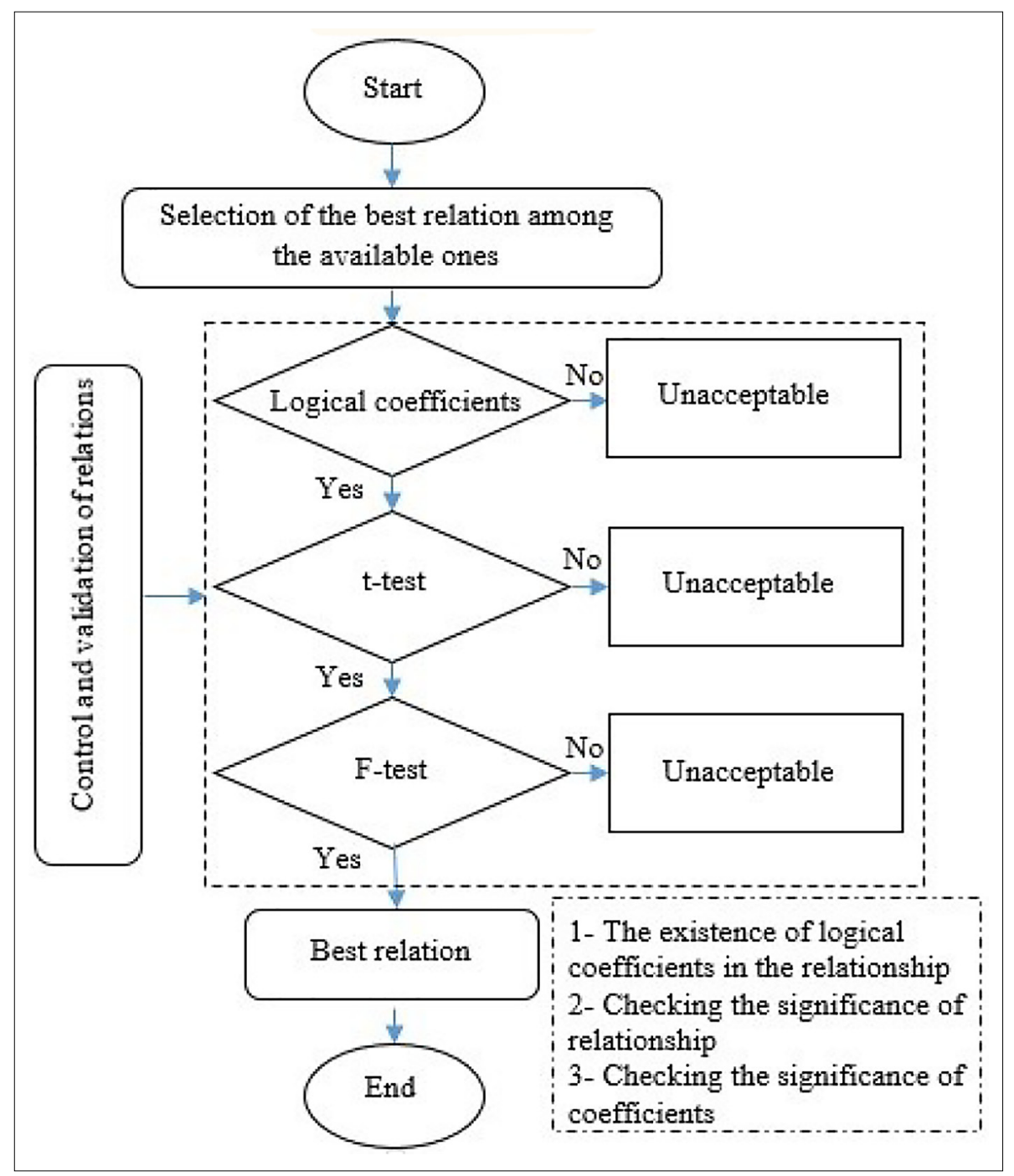

Figure 4: Relations control and validation stages 
MODEL1

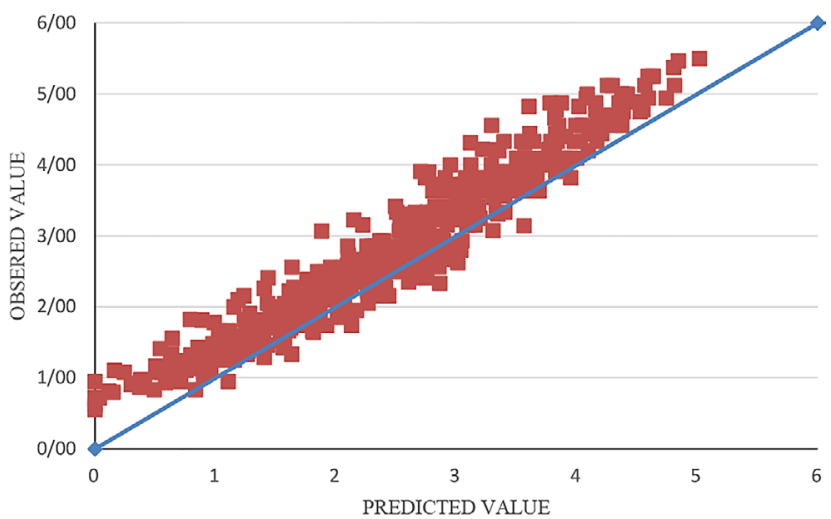

Figure 5: Dispersion of observed ROPs and ROPs predicted by Model 1 relative to the bisector

MODEL4

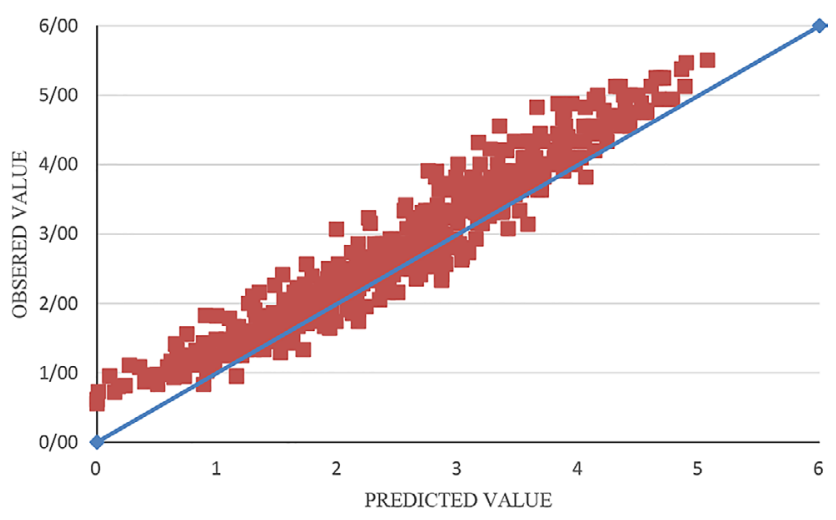

Figure 6: Dispersion of observed ROPs and ROPs predicted by Model 4 relative to the bisector

\section{MODEL 8}

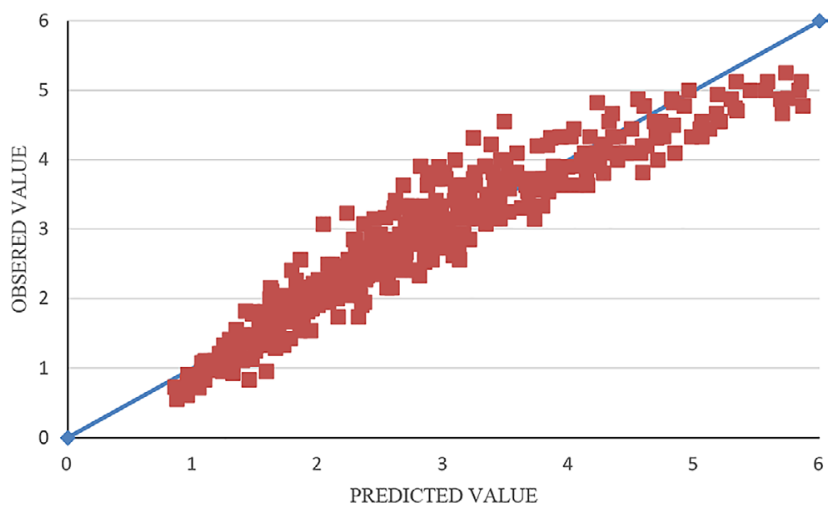

Figure 7: Dispersion of observed ROPs and ROPs predicted by Model 8 relative to the bisector

As shown in Figure 4, the F-test was used to control the significance of the model, and the t-test was used to control the significance of each independent variable.

Another way of evaluating statistical models is to analyze the dispersion of predicted and observed values around the bisector or calculate a correlation coefficient for the models. The more compact these points are
MODEL9

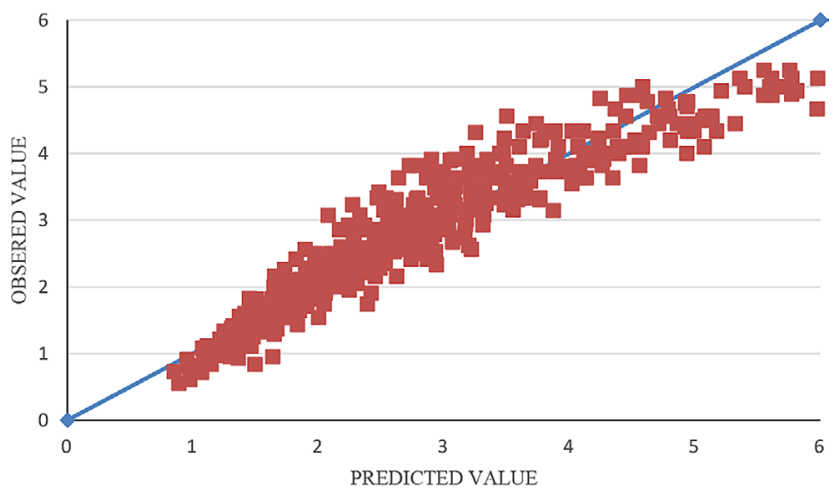

Figure 8: Dispersion of observed ROPs and ROPs predicted by Model 9 relative to the bisector

MODEL10

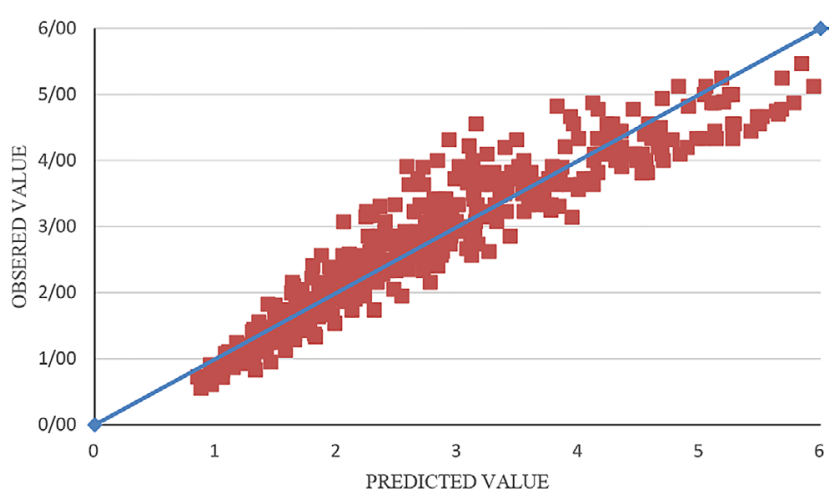

Figure 9: Dispersion of observed ROPs and ROPs predicted by Model 10 relative to the bisector

\section{MODEL13}

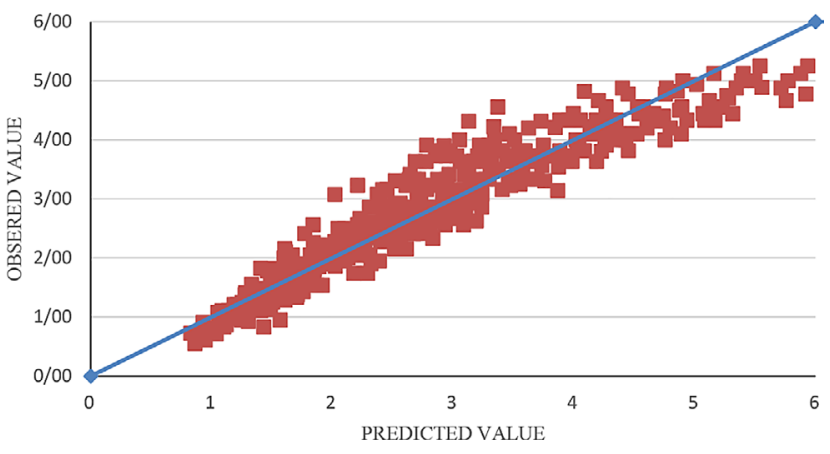

Figure 10: Dispersion of observed ROPs and ROPs predicted by Model 13 relative to the bisector

around the bisector and the higher is the correlation coefficients, the higher the model accuracy, or in other words, the lower the model estimation error. The correlation coefficients obtained for these models suggest that they all provide highly accurate ROP estimates. Figures 5 to $\mathbf{1 0}$ show the dispersion of observed ROPs and those predicted by the proposed models.

From the above diagrams, it can be concluded that models $1,4,8,9,10$ and 13 are highly accurate in producing ROP estimates. 


\section{Discussion}

Since the F statistic obtained for the models was greater than the $\mathrm{F}$ given in the F-distribution table for $99 \%$ confidence, the null hypothesis that there is no linear relationship between the dependent variable (ROP) and the independent variables (rock properties, fluid properties, and rig operating parameters) was rejected and it was concluded that at least one of the regression coefficients is not zero. After analyzing the overall significance of the model with the F-test, the significance of each independent variable was analyzed with the t-test. This test can be used to test the hypothesis of each coefficient being zero for each independent variable. Since in only some models the $t$ statistic of independent variables was greater than the $t$ statistic given in the t-distribution table for $90 \%$ confidence, the hypothesis that the coefficients of the independent variables are zero was rejected. The analysis of linear multivariate models showed that in Models 1 and 4, the t statistic obtained for the independent variables was greater than the $t$ in the relevant distribution table for $90 \%$ confidence. Therefore, for these models, the hypothesis that the coefficients of the independent variables are zero was rejected. In Models 2,3 , and 6 , the $t$ statistic obtained for the independent variable UCS was smaller than the $t$ given in the $t$-distribution table for $90 \%$ confidence. Therefore, Models 2, 3 , and 6 could not refute the hypothesis that the independent coefficients are zero. However, these models were able to reject this hypothesis at the $80 \%$ confidence level. In Models 5 and 7, the t statistic obtained for the independent variable Vis was smaller than the $t$ in the relevant distribution table for $90 \%$ confidence, indicating that they cannot refute the hypothesis that the independent coefficients are zero. The results of nonlinear multivariate models showed that in Models 8, 9, 10, and 13, the $t$ statistics obtained for independent variables were greater than the $\mathrm{t}$ in the relevant distribution table for $90 \%$ confidence, suggesting that the hypothesis that the coefficients of the independent variables are zero can be rejected. In Model 11, the $t$ obtained for the independent variable EC was smaller than the $\mathrm{t}$ given in the corresponding distribution table for $90 \%$ confidence. Thus, Model 11 could not refute the hypothesis that the independent coefficients are zero. However, this model was able to refute this hypothesis at a 70\% confidence level. In Model 12, the $t$ statistic obtained for the independent variable Vis was smaller than the $t$ given in the corresponding distribution table for $90 \%$ confidence, showing that it cannot refute the hypothesis that the independent coefficients are zero. In Model 14, the $t$ statistics obtained for the independent variables Vis and EC were smaller than the $\mathrm{t}$ given in the $\mathrm{t}$-distribution table for $90 \%$ confidence, which shows these models cannot refute the hypothesis that the independent coefficients are zero. One important consideration to make in statistical analysis, especially in the presentation of statistical models, is that whether coefficients can be reasonably justified, or in other words, whether the model matches the scientific rationale of the modelled phenomenon. In the context of this study, it is fairly reasonable to expect an inverse relationship between ROP and rock properties (strength, hardness, and abrasivity) for constant rig operating conditions and a positive relationship between ROP and rig operating parameters for a given rock with constant properties, and therefore any model that suggests the opposite is scientifically unacceptable. By this logic, it can be concluded the acceptable models are Models 1, 4, 8, 9, 10, and 13 with correlation coefficients of $0.930,0.931,0.919,0.909,0.905$, and 0.916 , respectively. Among these models, Model 4 has the highest correlation coefficient.

The diagrams of dispersion of real and predicted ROPs around the bisector also show that Models 1, 4, 8, 9, 10, and 13 provide highly accurate ROP estimates with an average estimation error of $16.65 \%, 14.82 \%$, $9.96 \%, 10.57 \%, 10.75 \%$, and $10.06 \%$, respectively. As these error rates show, Models 8 and 13 were able to produce ROP estimates with the lowest error for 492 data points collected from hard and soft rock samples for six drilling fluids.

\section{Conclusion}

This study investigated the relationship between ROP and mechanical properties of rocks, physical properties of drilling fluids, and rig operating parameters in the drilling of seven soft and hard rock samples with six fluids (water and five other cooling lubricating fluids). This investigation was performed by conducting 492 drilling tests on three samples of hard rock and four samples of soft rock and statistical analyses of the test results. Before starting the drilling tests, uniaxial compressive strength, Mohs hardness, Schmiazek abrasivity factor, and Young's modulus (representing respectively the strength, hardness, abrasivity, and elasticity/plasticity) of the collected rock samples and $\mathrm{pH}$, viscosity, and conductivity of the fluids were determined by laboratory testing. The drilling tests were performed with a laboratory-scale drilling rig with a diamond bit and different operating conditions. After collecting laboratory data, statistical analyses were performed in two parts: linear and nonlinear multivariate regression. During these analyses, 14 linear and nonlinear multivariate statistical models for ROP prediction were constructed with SPSS. A series of t-tests and F-tests were performed to analyze the statistical significance of the models and their coefficients. The model predictions were also analyzed to determine whether they are realistic. After these assessments, six models were judged in their suitability for predicting ROP. The results of the statistical tests of these models showed with over $90 \%$ confidence that they can produce highly accurate ROP estimates based on mechanical properties of the rock, physical characteristics of the cooling lubricating fluid, and operating pa- 
rameters of the drilling rig. These models were also compared in terms of their average estimation error and the two models with the lowest error rates were picked as the top choices for ROP prediction.

\section{References}

Aalizad, S.A. and Rashidinejad, F. (2012): Prediction of penetration rate of rotary-percussive drilling using artificial neural networks-a case study. Archives of Mining Sciences, 57(3), 715-728. https://doi.org/10.2478/v10267-0120046-X.

Altindag, R. (2004): Evaluation of drill cuttings in prediction of penetration rate by using coarseness index and mean particle size in percussive drilling. Geotechnical \& Geological Engineering, 22(3), 417-425. https://doi.org/10. 1023/B:GEGE.0000025043.92979.48.

Azar, H.F., Saksala, T. and Jalali, S.-M.E. (2017): Artificial neural networks models for rate of penetration prediction in rock drilling. Rakenteiden Mekaniikka, 50(3), 252-255. https://doi.org/10.23998/rm.64969.

Basarir, H., Tutluoglu, L. and Karpuz, C. (2014): Penetration rate prediction for diamond bit drilling by adaptive neurofuzzy inference system and multiple regressions. Engineering Geology, 173, 1-9. https://doi.org/10.1016/j. enggeo.2014.02.006.

Bhatnagar, A. and Khandelwal, M. (2012): An intelligent approach to evaluate drilling performance. Neural Computing and Applications, 21(4), 763-770. https://doi.org/ 10.1007/s00521-010-0457-6.

Bhatnagar, A., Khandelwal, M. and Rao, K. (2011): Laboratory investigations for the role of flushing media in diamond drilling of marble. Rock mechanics and rock engineering, 44(3), 349-356. https://doi.org/10.1007/s00603011-0144-7.

Bhatnagar, A., Khandelwal, M. and Rao, K.U.M. (2010): Enhancing diamond drilling performance by the addition of non-ionic polymer to the flushing media. Mining Science and Technology (China), 20(3), 400-405. https://doi. org/10.1016/S1674-5264(09)60215-5

Bilim, N. and Karakaya, E. (2021): Penetration Rate Prediction Models for Core Drilling. Mining, Metallurgy \& Exploration, 38(1), 359-366. https://doi.org/10.1007/s42461020-00322-6.

Brown, E.T. (1981): Rock characterization, testing \& monitoring: ISRM suggested methods. Oxford, Pergamon Press. 171-183.

Cheniany, A., Hasan, K.S., Shahriar, K. and Hamidi, J.K. (2012): An estimation of the penetration rate of rotary drills using the Specific Rock Mass Drillability index. International Journal of Mining Science and Technology, 22(2), 187-193. https://doi.org/10.1016/j.ijmst.2011.09.001

Clark, G.B. (1987): Principles of rock fragmentation. John Wiley \& Sons, United States, pp. 243-294

El-Shall, H., Gupta, S., Haecker, R. and Somasundaran, P. (2000): Effect of additives on drilling in hard rock. Mining Engineering, 52(1), 48-52.
Elkatatny, S., Al-AbdulJabbar, A. and Abdelgawad, K. (2020): A new model for predicting rate of penetration using an artificial neural network. Sensors, 20(7), 2058. https://doi. org/10.3390/s20072058.

Ersoy, A. and Waller, M. (1995): Textural characterisation of rocks. Engineering geology, 39(3-4), 123-136. https://doi. org/10.1016/0013-7952(95)00005-Z

Gupta, A., Chattopadhyaya, S. and Hloch, S. (2013): Critical investigation of wear behaviour of WC drill bit buttons. Rock mechanics and rock engineering, 46(1), 169-177. https://doi.org/10.1007/s00603-012-0255-9.

Hammond, M. and Ravitz, S. (1963): Influence of environment on brittle fracture of silica. Journal of the American Ceramic Society, 46(7), 329-332. https://doi.org/10.1111 /j.1151-2916.1963.tb11740.x.

Hoseinie, S., Aghababaei, H. and Pourrahimian, Y. (2008): Development of a new classification system for assessing of rock mass drillability index (RDi). International Journal of Rock Mechanics and Mining Sciences, 45(1), 1-10. https://doi.org/10.1016/j.ijrmms.2007.04.001.

Kahraman, S. (1999): Rotary and percussive drilling prediction using regression analysis. International journal of rock mechanics and mining sciences, (1997), 36(7), 981-989. https://doi.org/10.1016/S0148-9062(99)00050-9.

Khoshouei, M., Bagherpour, R., Jalalian, M.H. and Yari, M. (2020): Investigating the acoustic signs of different rock types based on the values of acoustic signal RMS. Rudarsko-geološko-naftni zbornik, 35(3), 29-38. https:// doi.org/10.17794/rgn.2020.3.3.

Kivade, S., Murthy, C.S. and Vardhan, H. (2015a): Experimental investigations on penetration rate of percussive drill. Procedia Earth and Planetary Science, 11, 89-99. https://doi.org/10.1016/j.proeps.2015.06.012.

Kivade, S.B., Murthy, C.S.N. and Vardhan, H. (2015b): ANN models for prediction of sound and penetration rate in percussive drilling. Journal of The Institution of Engineers (India), Series D 96(2), 93-103. https://doi.org/10.1007/ s40033-015-0067-7.

Lawal, A.I., Kwon, S. and Onifade, M. (2021): Prediction of rock penetration rate using a novel Antlion optimized ANN and statistical modelling. Journal of African Earth Sciences, 104287. https://doi.org/10.1016/j.jafrearsci. 2021.104287.

Liao, X., Khandelwal, M., Yang, H., Koopialipoor, M. and Murlidhar, B.R. (2020): Effects of a proper feature selection on prediction and optimization of drilling rate using intelligent techniques. Engineering with Computers, 36(2), 499-510. https://doi.org/10.1007/s00366-019-00711-6.

Loui, P.J. and Rao, K. (1997): Experimental investigations of pick-rock interface temperature in drag-pick cutting. International Journal of Engineering and Material Sciences, 4(2), 63-66. http://nopr.niscair.res.in/handle/123456789/ 29717.

Miller, D. and Ball, A. (1990): Rock drilling with impregnated diamond microbits - an experimental study. International Journal of Rock Mechanics and Mining Sciences \& Geomechanics Abstracts, Elsevier, 27(5), 363-371. https:// doi.org/10.1016/0148-9062(90)92711-M. 
Miller, D. and Ball, A. (1991): The wear of diamonds in impregnated diamond bit drilling. Wear, 141(2), 311-320. https://doi.org/10.1016/0043-1648(91)90276-Z.

Mills, J. and Westwood, A. (1978): Influence of chemomechanically active fluids on diamond wear during hard rock drilling. Journal of Materials Science, 13(12), 2712-2716. https://doi.org/10.1007/BF00552703.

Moraveji, M.K. and Naderi, M. (2016): Drilling rate of penetration prediction and optimization using response surface methodology and bat algorithm. Journal of Natural Gas Science and Engineering, 31, 829-841. https://doi.org/ 10.1016/j.jngse.2016.03.057.

Pahlman, J.E. (1989): Zero-surface-charge-controlled drilling for enhanced penetration and extended bit life, US Department of the Interior, Bureau of Mines.

Rao, K.U. (1993): Experimental and theoretical investigation of drilling of rocks by impregnated diamond core bits. IIT, Kharagpur. Ph.D. thesis.

Rawal, R., Karmakar, N. and Sharma, S. (2016): Effect of fluid additives on rock drilling. Advances in Engineering Research, 2352-5401. https://doi.org/10.2991/rare-16.2016.34.

Selim, A., Schultz, C. and Strebig, K. (1969): The Effect of Additives on Impregnated Diamond Bit Performance. Society of Petroleum Engineers Journal, 9(04), 425-433. https://doi.org/10.2118/2387-PA.

Shad, H.I.A., Sereshki, F., Ataei, M. and Karamoozian, M. (2018): Prediction of rotary drilling penetration rate in iron ore oxides using rock engineering system. International Journal of Mining Science and Technology, 28(3), 407413. https://doi.org/10.1016/j.ijmst.2018.04.004.

Staroselsky, A. and Kim, K. (1997): An analytical elucidation of the influence of surfactant on rock drilling by shear/drag bit. Rock mechanics and rock engineering, 30(3), 145-159. https://doi.org/10.1007/BF01047390.

Taheri, A., Qao, Q. and Chanda, E. (2016): Drilling penetration rate estimation using rock drillability characterization index. Journal of The Institution of Engineers (India), Series D 97(2), 159-170. https://doi.org/10.1007/s40033015-0104-6.

Tuzinski, P.A., Pahlman, J.E., Watson, P.J. and Engelmann, W.H. (1989): Enhanced Well-Drilling Performance with Chemical Drilling-Fluid Additives. IC-USBM9216, 86-107.

Tweeton, D.R. (1976): Influence of Surface-active Chemicals on Drilling and Fracturing Rock. US Department of the Interior, Bureau of Mines, RI 8186.
Van Hung, N., Gerbaud, L., Souchal, R., Urbanczyk, C. and Fouchard, C. (2016): Penetration rate prediction for percussive drilling with rotary in very hard rock. Journal of Science and Technology, 54(1), 133-149. https://hal.archives-ouvertes.fr/hal-01521017.

Westwood, A., Ahearn, J. and Mills, J. (1981): Developments in the theory and application of chemomechanical effects. Colloids and Surfaces, 2(1), 1-35. https://doi.org/ 10.1016/0166-6622(81)80050-9.

Yagiz, S. and Karahan, H. (2015): Application of various optimization techniques and comparison of their performances for predicting TBM penetration rate in rock mass. International Journal of Rock Mechanics and Mining Sciences, 80,308-315.https://doi.org/10.1016/j.ijrmms.2015.09.019.

Yari, M. and Bagherpour, R. (2018a): Implementing acoustic frequency analysis for development the novel model of determining geomechanical features of igneous rocks using rotary drilling device. Geotechnical and Geological Engineering, 36(3), 1805-1816. https://doi.org/10.1007/ s10706-017-0433-3.

Yari, M. and Bagherpour, R. (2018b): Investigating an innovative model for dimensional sedimentary rocks characterization using acoustic frequencies analysis during drilling. Rudarsko-geološko-naftni zbornik, 33(2), 17-25. https:// doi.org/10.17794/rgn\%20zbornik.v33i2.5646.

Yari, M., Bagherpour, R. and Khoshouei, M. (2019): Developing a novel model for predicting geomechanical features of carbonate rocks based on acoustic frequency processing during drilling. Bulletin of Engineering Geology and the Environment, 78(3), 1747-1759. https://doi.org/10.1007/ s10064-017-1197-y.

Yassien, M.A., Sayed, M.A., Boghdady, G.Y., Ali, M.A. and Mohamed, A.S. (2020): Experimental research into the effect of some operation factors and rock properties on the rate of penetration. Mining of Mineral Deposits, 14(1), 3643. https://doi.org/10.33271/mining14.01.036.

Zhao, X.H., Gao, F., Li, Y.F. and Li, W. (2011): The research on the effect of drilling fluids additives on Rate of Penetration (ROP). Advanced Materials Research, Trans Tech Publ. 2064-2071. https://doi.org/10.4028/www.scientific. net/AMR.239-242.2064.

Zhao, Y., Noorbakhsh, A., Koopialipoor, M., Azizi, A. and Tahir, M. (2020): A new methodology for optimization and prediction of rate of penetration during drilling operations. Engineering with Computers, 36(2), 587-595. https://doi. org/10.1007/s00366-019-00715-2. 


\section{SAŽETAK}

\section{Eksperimentalno istraživanje utjecaja fluida za hlađenje i podmazivanje na napredak bušenja u mekim i tvrdim stijenama}

Bušenje stijena proces je prodiranja u stijenu i njezina razrušavanja te je karakteriziran malim napretkom bušenja i brzinom bušenja zbog količine nabušenih krhotina koje ostaju u izbušenome kanalu te termalnih naprezanja nastalih na kontaktu stijene i dlijeta. Svako poboljšanje u napretku bušenja i brzini bušenja bilo bi dodatna tehnička i ekonomska vrijednost u projektima bušenja. Napredak bušenja može se poboljšati pravilnom upotrebom fluida za hlađenje i podmazivanje tijekom samoga bušenja. Također, napredak bušenja ključni je pokazatelj performansi procesa bušenja, a njegovo predviđanje može biti vrlo korisno u rudarskim projektima te se može iskoristiti za procjenu ukupnih troškova bušaćih operacija. Napredak bušenja ovisi o različitim parametrima koji, kada su dostupni, mogu biti iskorišteni za njegovu procjenu. Kako bi se bolje razumjelo parametre koji utječu na napredak bušenja te kako ih optimirati, u ovome istraživanju analizirani su rezultati 492 laboratorijska testa bušenja s pomoću linearne i nelinearne multivarijantne regresije u programu SPSS (statistički paket koji se koristi u društvenim znanostima) kako bi se razvili modeli za predviđanje napretka bušenja. Testovi su provedeni na sedam uzoraka meke i tvrde stijene uz primjenu šest fluida za hlađenje i podmazivanje. Za njihovu provedbu korištena je laboratorijska bušilica za bušenje kubičnih uzoraka, uz primjenu različitih brzina rotacije i opterećenja. Dobiveni rezultati upućuju na znatno povećanje napretka bušenja kod primjene fluida za hlađenje i podmazivanje. Nakon analize utvrđeno je da nekoliko modela može predvidjeti napredak bušenja s najnižom srednjom pogreškom procjene te da su oni pogodni za predviđanje napretka bušenja u situaciji kada se koristi fluid za hlađenje i podmazivanje. Rezultati statističke obrade podataka pokazuju da ti modeli mogu jako precizno procijeniti napredak bušenja s pouzdanošću većom od $90 \%$ na temelju svojstava stijene, fizičkih karakteristika fluida za hlađenje i podmazivanje te radnih parametara bušaćega postrojenja.

\section{Ključne riječi:}

bušenje, napredak bušenja, fluid za hlađenje i podmazivanje, multivarijantna statistička analiza, program SPSS

\section{Author's contribution}

Shahrokh Khosravimanesh (PhD Candidate): participated in all work stages such as providing samples, running experimental tests and data analyses. Masoud Cheraghi Seifabad (Associate Professor): shared contributions throughout the whole process and data analyses. Reza Mikaeil (Associate Professor): managed the whole process and supervised it from the beginning to the end. Raheb Bagherpoor (Full Professor): shared contributions in collecting different studies. 